\title{
WUNDERLICH SYNDROME (SPONTANEOUS SUBCAPSULAR RENAL HAEMORRHAGE) ASSOCIATED WITH RENAL ABSCESS: CT IMAGING OF PRE-RENAL AND POST-RENAL DRAINAGE
}

\author{
Salazar-Ruiz S.Y.' , Nino-Najera W. ${ }^{2}$, Roldan-Valadez E. ${ }^{1,3}$
}

\footnotetext{
1 - Directorate of Research, Hospital General de Mexico "Dr Eduardo Liceaga”. Mexico City, Mexico.

2 - Urology unit. Hospital Militar Regional de Especialidades de Merida. Merida city, Yucatan state, Mexico.

3 - I.M. Sechenov First Moscow State Medical University (Sechenov University), Moscow, Russia.
}

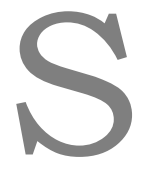

pontaneous subcapsular renal bleeding is an uncommon condition that is unusually caused by obstructive uropathy. We present an unusual case of a 58 -year-old female patient who presented with sudden onset right-sided flank pain associated with nausea, vomiting and fever. The diagnosis was confirmed by contrast-enhanced computed tomography, but it was not easy to propose a treatment when the aetiology is not precise. Imaging follow-up and therapeutic approach are discussed. Our case is original as one of the few reports with conservative management after the drained renal abscess and obstruction caused by the spontaneous renal haemorrhage.

Keywords: kidney calculi; hematoma; Wunderlich syndrome.

Corresponding author: Ernesto Roldan-Valadez e-mail: ernest.roldan@usa.net

For citation: Salazar-Ruiz S.Y, Nino-Najera W., Roldan-Valadez E. Wunderlich syndrome (spontaneous subcapsular renal haemorrhage) associated with renal abscess: CT imaging of pre-renal and post-renal drainage. REJR 2021; 11 (2):233-237. DOI: 10.21569/2222-7415-2021-11-2-233-237.

Received: $\quad 09.05 .21 \quad$ Accepted: 25.06 .21

\section{СИНАРОМ ВУНАЕРАИХА (СПОНТАННОЕ СУБКАПСУАЯРНОЕ ПОЧЕЧНОЕ КРОВОТЕЧЕНИЕ), СВЯЗАННЫЙ С АБСЦЕССОМ ПОЧКИ: КТ АО И ПОСАЕ АРЕНИРОВАНИЯ}

\author{
Salazar-Ruiz S.Y.' ', Nino-Najera W. 2, Roldan-Valadez E. ${ }^{1,3}$ \\ 1- Отдел исследований, Hospital General de Mexico «Dr Eduardo Liceaga». г. Мехико, Мексика. \\ 2 - Урологическое отделение, Больница Militar Regional de Especialidades de Merida. г. Мерида, штат Юкатан, Мексика. \\ 3 - Первый Московский государственный медицинский университет им. И.М. Сеченова (Сеченовский университет). \\ г. Москва, Россия.
}

понтанное субкапсулярное почечное кровотечение - редкое заболевание, которое обычно спровоцировано обструктивной уропатией. Мы представляем необычный случай, когда у 58-летней пациентки возникла внезапная боль в правом боку, которая сопровождалась тошнотой, рвотой и михорадкой. Диагноз был подтвержден с помощью компьютерной томографии с контрастным усилением, но было затруднительно назначить мечение, т.к. этиология быма до конца неясной. Дальнейший КТ-контроль и терапевтический подход являлись объектом обсуждения. Данный случай явцяется оригинальным, одним из небольшого списка сообщений о консервативном мечении после дренирования почечного абсцесса и обструкции, вызванной спонтанным почечным кровотечением.

Ключевые слова: камни в почках, гематома, Синдром Вундерлиха. 


\section{RUSSIAN ELECTRONIC JOURNAL OF RADIOLOGY}

Контактный автор: Ernesto Roldan-Valadez. e-mail: ernest.roldan@usa.net

Для иитирования: Salazar-Ruiz S.Y., Nino-Najera W., Roldan-Valadez E. Синдром вундерлиха (спонтанное субкапсулярное почечное кровотечение), связанный с абсиессом почки: КТ до $u$ после дренирования. REJR 2021; 11(2):233-237. DOI: 10.21569/2222-7415-2021-11-2-233-237.

\section{Статья получена: $\quad$ 09.05.21 $\quad$ Статья принята: $\quad$ 25.06.21}

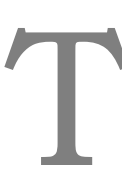

he spontaneous subcapsular or perirenal haemorrhage (Wunderlich's syndrome) is an uncommon clinical condition in the urology practice, the publications in the medical literature about this pathology are scarce [1].

The mortality rate associated with this problem is high; in most cases, emergency treatment could imply an explorative laparotomy through posterior lumbotomy and probably radical nephrectomy. examination, she presented pain to the palpation of mesogastrium and percussion of the right renal fossa; her vital signs were as follows: temperature $38^{\circ} \mathrm{C}$, blood pressure $118 / 68 \mathrm{mmHg}$, pulse rate 90 beats/min, and respiratory rate 15 breaths/min. Laboratory tests revealed a haemoglobin value of $8.7 \mathrm{~g} / \mathrm{dL}$ and creatinine of 2.17 $\mathrm{mg} / \mathrm{dL}$. On imaging, abdominal ultrasound (US) reported an increase in diameter in the right kidney; because of US findings, a dual-phase abdominopelvic computed tomography (CT) was request-

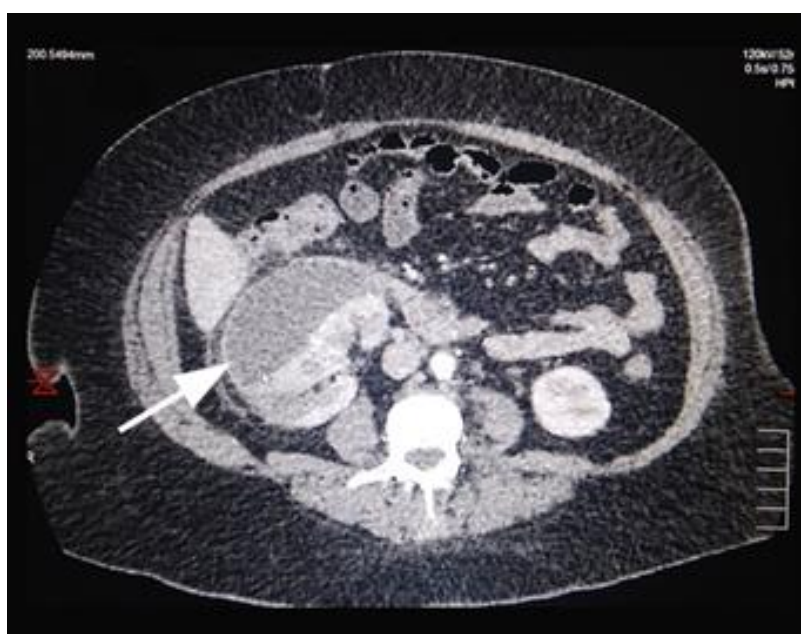

Fig. 1 a (Рис. 1 a)

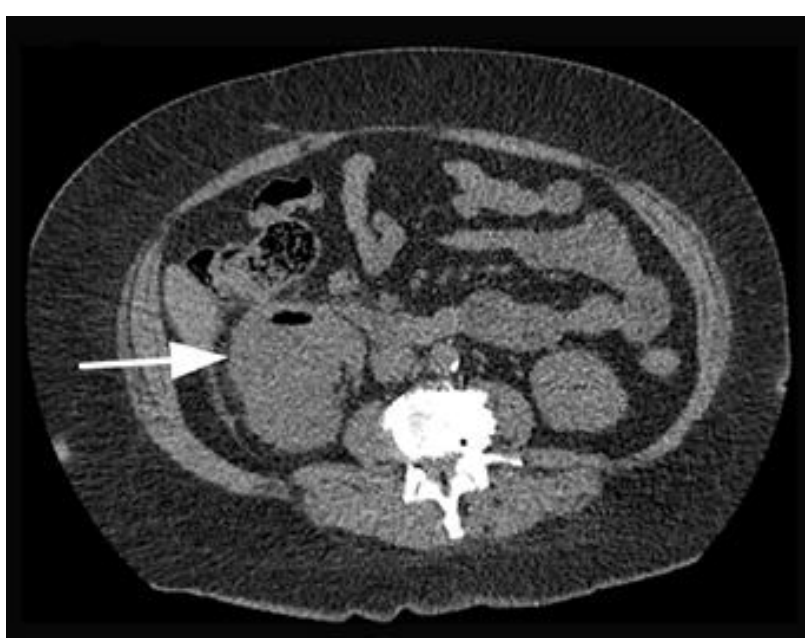

Fig. 16 (Рис. 1 b)

\section{Fig. 1. Renal CT.}

a - enhanced CT shows the subcapsular right renal haematoma (arrow). b - non-enhanced CT 2 months later revealed a subcapsular renal collection with access formation.

\section{Рис. 1. КТ почек.}

а - КТ после внутривенного контрастирования выявляет субкапсулярную гематому правой почки (стрелка). б - нативная КТ через 2 месяца выявила субкапсулярный абсцесс с возможным местом доступа для дренирования.

\section{Case report.}

A 58-year-old female attended the emergency department of a regional military hospital, with sudden onset of right flank pain of eight days duration, with 7/10 intensity on the analogous visual scale of pain, associated with nausea, vomiting and fever. She also reported intense dysuria with apparent stone expulsion. She had a history of diabetes, systemic arterial hypertension (for 15 years) and nephrolithiasis. On general physical ed. CT reported a right perirenal collection with at subcapsular right renal haematoma more evident after contrast enhancement administration (Fig. 1a).

Patient received conservative management with antibiotics and analgesics; after two weeks, a new abdominal CT showed satisfactory haematoma resolution (CT images not available). Two weeks after admission, she was discharged with a scheduled appointment in the outpatient urology 


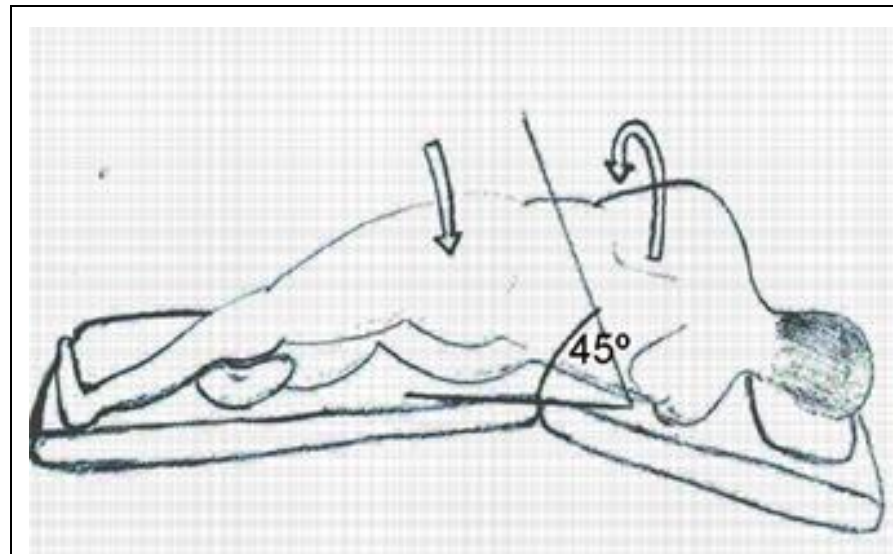

Fig. 2 a (Рис. 2 a)

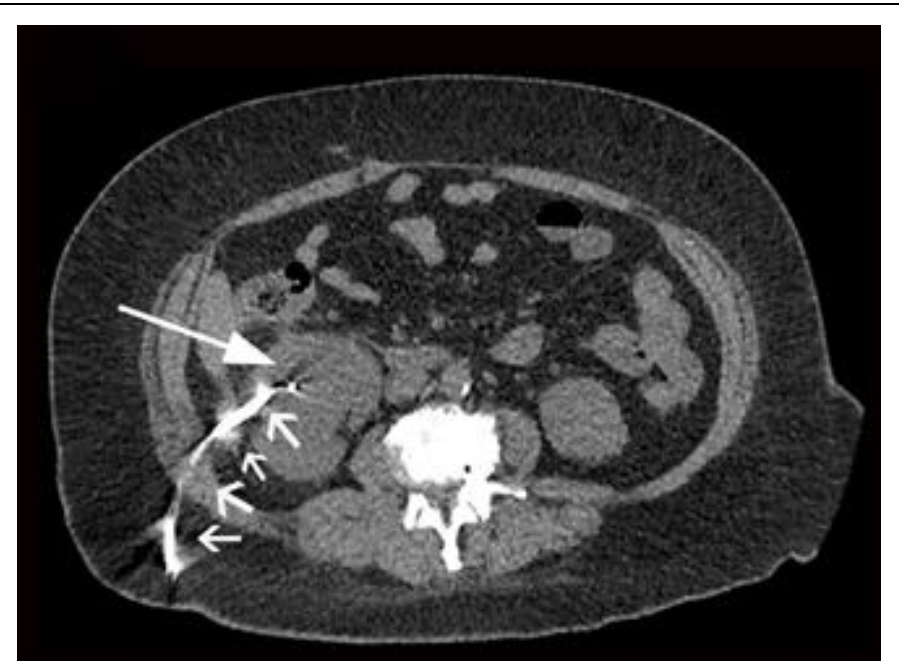

Fig. 2 с (Рис. 2 в)

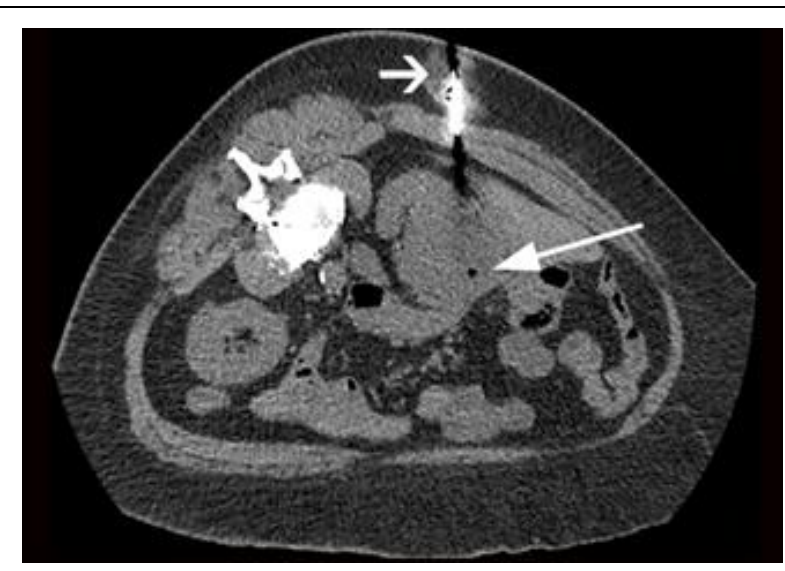

Fig. 26 (Рис. 2 b)

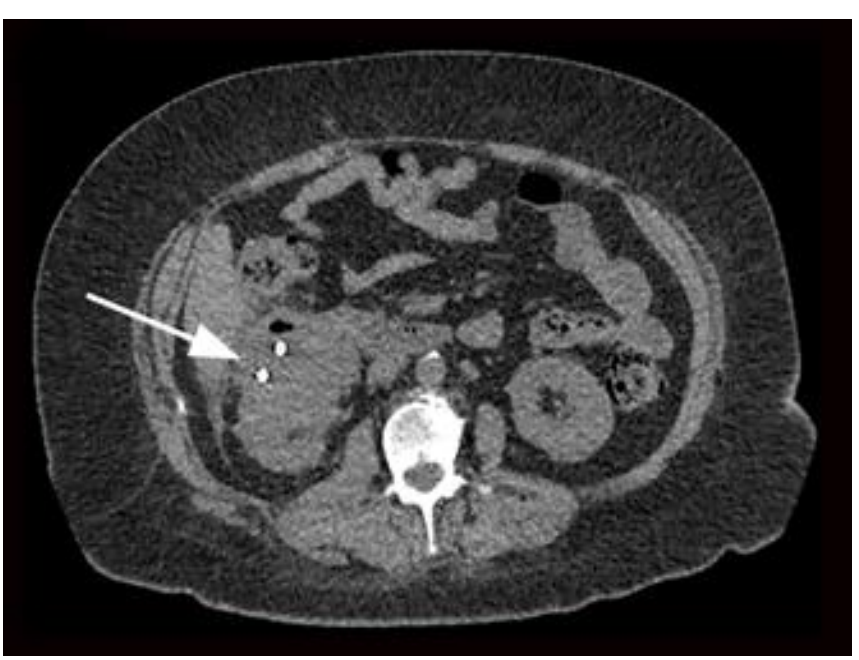

Fig. 2 d (Рис. 2 г)

\section{Fig. 2. Follow-up non-enhanced renal CT.}

$\mathrm{a}$ - scheme of the lumbotomy position. $\mathrm{b}$ - abdominal CT in lumbotomy position. Insertion of the drainage catheter (short white arrows) in the renal abscess (long white arrow). c - abdominal CT in dorsal decubitus position, one hour later, showed adequate drainage of more than $80 \%$ of the renal abscess. $\mathrm{d}$ - abdominal CT in dorsal decubitus position, a week later showed resolution of the previous subcapsular collection and haematoma; the tips of the catheter are pointed (white arrow).

\section{Рис. 2. КТ почек без контрастного иусиления».}

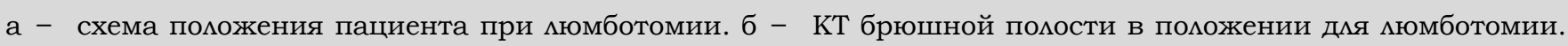
Введение дренажного катетера (короткая стрелка) в абсцесс почки (длинная стрелка). в - КТ брюшной помости в положении на спине через час. Адекватный дренаж более чем 80\% почечного абсцесса (длинная стрелка). г - КТ брюшной полости через неделю. Зафиксировано разрешение процесса (белая стрелка).

clinic for two months. Non-enhanced abdominal CT at this time revealed a subcapsular renal collection (Fig. 1b). With suspicion of an abscess, the patient underwent percutaneous drainage, and 30 $\mathrm{ml}$ of non-fetid purulent fluid was obtained (Fig. $2 \mathrm{a}, 2 \mathrm{~b}, 2 \mathrm{c})$; the renal abscess was drained more than $80 \%$, percutaneous drainage was left. An abdominal CT a week later revealed resolution of the previous subcapsular collection and haematoma (Fig.2d).

The patient was discharged; a three-month follow up showed an asymptomatic patient, her right kidney did not present a new collection and haematoma.

\section{Discussion.}

Spontaneous non-traumatic subcapsular haemorrhage is a rare condition described by Carl Reinhold Wunderlich in 1856 . He referred to it as a spontaneous renal haematoma in the perirenal or subcapsular region [2]. Recent reviews reported renal tumour incidence producing spontaneous subcapsular haematoma of $61.5 \%$; the most 


\section{RUSSIAN ELECTRONIC JOURNAL OF RADIOLOGY}

common benign neoplasm was angiomyolipoma $33 \%$, while renal cell carcinoma was the most common malignant neoplasm in 24\% [3-5]. Other reported causes include vascular diseases in $17 \%$, idiopathic origin in $6.7 \%$ and infections in $2.4 \%$; among infections appear nephritis in $16.85 \%$ and tuberculosis in $2.2 \%[3,4,6,7]$. Singh V. et al. described other causes of spontaneous renal haematoma: invasive mole, antiplatelet therapy, anticoagulated patient, after ureteroscopy and lithotripsy with holmium laser [8].

In view that the aetiology of spontaneous subcapsular haematoma could not be determined in our patient, the diagnosis of exclusion was obstructive uropathy with hydronephrosis caused by a ureteral calculus. We considered our case is relevant because previews reports of spontaneous subcapsular haematoma have been associated with urolithiasis in patients who received extracorporeal shock wave lithotripsy and ureteroscopic lithotripsy; however, our patient did not receive these procedures [9]. Our report consisted of identifying spontaneous subcapsular hematoma secondary to a ureteral obstruction that has not been described previously. To the best of our knowledge, obstructive uropathy has not been reported for this kind of situation.

It has been observed that hydronephrosis for a long time causes a spontaneous rupture of the fornix; It is the weakest point in the pyelocalicial system, with the consequent extravasation of urine and haematoma formation. The ureteral cal culus is the most common cause of fornix rupture [10]. In our patient, the ureteral calculus was not found, and she did not present urinoma. Nevertheless, she had a history of nephrolithiasis. So, it could be a possibility that after the stone was expelled, there was a sudden decrease in the pressure in the urinary tract, causing the fornix to rupture and, as a consequence, giving rise to a subcapsular hematoma. The clinical vignette or Lenk's triad is present in some patients: acute

\section{References:}

1. Kim J.W., Kim J.Y., Ahn S.T., Park T.Y., Oh M.M., Moon D.G., Park H.S. Spontaneous perirenal hemorrhage (Wunderlich syndrome): An analysis of 28 cases. The American journal of emergency medicine, 2018. doi:10.1016/j.ajem.2018.04.045

2. Sierra-Diaz E., Belmonte-Hernandez M.V., Villanueva-Perez M.A., Garcia-Gutierrez M. Non-traumatic spontaneous retroperitoneal bleeding: the effect of an early and accurate diagnosis.

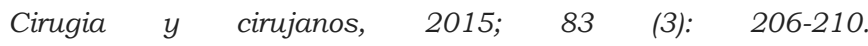
doi:10.1016/j.circir.2015.05.014

3. Baishya R.K., Dhawan D.R., Sabnis R.B., Desai M.R. Spontaneous subcapsular renal hematoma: A case report and review of literature. Urology annals, 2013; 3 (1): 44-46. doi:10.4103/0974-7796.75852

4. Choi H.I., Kim Y.G., Kim S.Y., Jeong D.W., Kim K.P., Jeong K.H., Lee S.H., Moon J.Y. Bilateral Spontaneous Perirenal Hem- abdominal pain, mainly in the flank, palpable mass and hypovolemic shock; of these three signs, our patient presented severe pain in the right flank [11].

The diagnosis was made with images studies which allowed us to discard infections and malignant tumours. The first step is the US due to easy availability; it shows the different collection grades in the perirenal and subcapsular space, but it is not confirmatory $[8,12]$. It is operator dependent. The diagnosis has to be confirmed by contrastenhanced CT; it is the best imaging test because we can delimit the haematoma size, its origin and helps us to discard a differential diagnosis of rupture of an aneurysm in the abdominal aorta [13]. Bosniak believes that using contrast-enhanced CT with $5 \mathrm{~mm}$-thickness slices is sufficient to make an accurate diagnosis then an exploratory laparotomy is not necessary [14].

In comparison, Kendall et al. recommended a nephrectomy due to the high incidence of small tumours associated with this condition, even though there is no definite diagnosis, and the contralateral kidney is functionally normal [15]. Reviews of the literature have proposed at least three treatment options: conservative management with antibiotics and analgesics when the aetiology is not precise [8, 16, 17]. Greco M. et al. proposed conservative management with continuous monitoring of blood studies and ultrasound; severe cases could require radical nephrectomy [12, 15].

One of the most common complications of haematoma is the formation of abscesses, sepsis or retroperitoneal fibrosis [10]. As a consequence, our patient weeks later had an abscess that resolved with percutaneous drainage.

Because this patient was not finding the aetiology of spontaneous subcapsular renal haematoma, then our diagnosis of exclusion was the rupture of the fornix secondary to obstructive uropathy.

orrhage due to Initial Presentation of Polyarteritis Nodosa. Case reports in medicine. 2015: 428074. doi:10.1155/2015/428074 5. Ploumidis A., Katafigiotis I., Thanou M, Bodozoglou N., Athanasiou L., Ploumidis A. Spontaneous Retroperitoneal Hemorrhage (Wunderlich Syndrome) due to Large Upper Pole Renal Angiomyolipoma: Does Robotic-Assisted Laparoscopic Partial Nephrectomy Have a Role in Primary Treatment? Case reports in urology. 2013: 498694. doi:10.1155/2013/498694

6. Zhang J.Q., Fielding J.R., Zou K.H. Etiology of spontaneous perirenal hemorrhage: a meta-analysis. The Journal of urology. 2002; 167 (4): 1593-1596.

7. Pollack H.M., Popky G. Spontaneous subcapsular renal hemorrhage: its significance and roentgenographic diagnosis. The Journal of urology. 1972; 108 (4): 530-533.

8. Singh V., Jayaram S., Kumar D.B. Spontaneous Subcapsular 


\section{RUSSIAN ELECTRONIC JOURNAL OF RADIOLOGY}

Renal Haematoma: A Case Report. Journal of clinical and diagnostic research: JCDR. 2017; 11 (8):1314.doi:10.7860/jcdr/2017/27901.10435

9. Petros F.G., Zynger D.L., Box G.N., Shah K.K. Perinephric Hematoma and Hemorrhagic Shock as a Rare Presentation for an Acutely Obstructive Ureteral Stone with Forniceal Rupture: A Case Report. Journal of endourology case reports. 2016; 2 (1): 74-77. doi:10.1089/cren.2016.0033

10. Alandete S., Uceda D., Monedero M.D. Uropatía obstructiva litiásica con rotura de fórnix calicial y urinoma perirrenal secundario. Revista Argentina de Radiología. 2016; 80 (4): 295297. doi:10.1016/j.rard.2016.06.007

11. Parameswaran B., Khalid M., Malik N. Wunderlich syndrome following rupture of a renal angiomyolipoma. Annals of Saudi medicine. 2006; 26 (4): 310-312.

12. Greco M., Buttice S., Benedetto F., Spinelli F., Traxer O., Tefik T., Pappalardo R., Magno C. Spontaneous Subcapsular Renal Hematoma: Strange Case in an Anticoagulated Patient with HWMH after Aortic and Iliac Endovascular Stenting Procedure. Case reports in urology. 2016: 2573476. doi:10.1155/2016/2573476

13. Medda M., Picozzi S.C., Bozzini G., Carmignani L. Wunderlich's syndrome and hemorrhagic shock. Journal of emergencies, trauma, and shock. 2009; 2 (3):203-205. doi:10.4103/0974 2700.55346

14. Bosniak M.A. Spontaneous subcapsular and perirenal hematomas. Radiology. 1989; 172 (3):601-602. doi:10.1148/ radiology.172.3.2772165

15. Kendall A.R., Senay B.A., Coll M.E. Spontaneous subcapsular renal hematoma: diagnosis and management. The Journal of urology. 1988; 139 (2):246-250.

16. Powell P.H., Giddings A.E. Safeguarding the kidney after non-traumatic perirenal haemorrhage. British journal of urology. 1981; 53 (3):210-211.

17. Chaabouni A., Binous M.Y., Zakhama W., Chrayti H., Sfaxi M., Fodha M. Spontaneous calyceal rupture caused by a ureteral calculus. African Journal of Urology. 2013; 19 (4):191-193. doi:https://doi.org/10.1016/j.afju.2013.09.001 